\title{
CORPORATE TAX BURDEN IN THE CZECH REPUBLIC AND EUROPEAN UNION
}

\author{
Ivana Koštuř́íková
}

\section{Klíčová slova:}

daňové zatîžení firem, Česká republika, Evropská unie, daňový mix, statutární zdanění, implicitní zdanění

\section{Key words:}

corporate tax burden, Czech Republic, European Union, tax mix, statutory taxation, implicit taxatin

\begin{abstract}
Abstrakt
Cílem příspěvku je zhodnotit vývoj a současný stav daňového zatížení firem v České republice jako významného faktoru rostoucí konkurence mezi jednotlivými zeměmi Evropské unie se zaměřením na statutární a implicitní sazby daně z př́ijmů právnických osob. Komparace implicitních daňových sazeb napříč jednotlivými státy poskytuje indikace, zda zde existují podstatně odlišné daňové přístupy ke společnostem se stejnými charakteristikami, ale dislokovanými v různých zemích.
\end{abstract}

\begin{abstract}
The objective of this contribution is to assess the development and the current state of the tax burden in the Czech Republic as a significant factor of the growing competition among the individual European Union countries, concentrating on the statutory and implicit corporate income tax rates. Comparison of the implicit tax rates across the individual countries provides indications whether substantially different tax approaches exist to companies with identical characteristics, but dislocated in different countries.
\end{abstract}

\section{Introduction}

As far as decisions of corporate management are concerned, the taxation system is one of the decisive factors. The taxation environment in which a company operates affects the amount and distribution of the disposable profit, a selection of optimal financial and asset structure, investments etc. It is directly related to the financial position of the company, its individual activities and affects also production factors. For the foreign investors the amount of burden is one of the significant factors affecting the selection of the place of business.

Taxes are defined ${ }^{1}$ as mandatory, irrecoverable payments stipulated by law to the public budget. They are a non-purpose and non-equivalent payment. They repeat regularly in time intervals (for instance, income tax payment on an annual basis), or irregular and are paid under certain circumstances (for instance, on each transfer of real estates). In the society, taxes fulfil a number of significant functions and their role results from the major economic functions of the public sector. The most important functions include allocation, nondistribution, stabilisation and fiscal functions. In the event of expressions of ineffectiveness of the market in allocation of resources, the allocation function is applied, when taxes may affect distribution of funds to those areas (sectors), which fall under the state interest (e.g. via tax

\footnotetext{
${ }^{1}$ KUBÁTOVÁ, K. Daňová teorie a politika. Edition 4. Prague: ASPI, 2006. ISBN 80-7357-205-2. p. 16.
} 
relieves or tax holidays as long as certain conditions are met related to the investment volume, new technologies, opening new job positions, etc.). In the event that taxes fulfil this function, we speak of so-called indirect financing or a tax aid. The goal of the redistribution function primarily rests in removal of considerable differences in distribution of wealth. The state (government) via taxes takes away a part of created income from their owners and using payments of different kinds (transfers) balances out these differences. The method of distribution and identification of the place of use of the created funds is a complicated and politically sensitive issue. The stabilisation function of taxes is an integral part of the economic policy, by which taxes may alleviate cyclical fluctuations in the economy. At the time of prosperity, when income as well as consumption rises, taxes bring a higher proportion to the public budgets and hence help to prevent from overheating the economy; on the contrary, at the time of recession, or a in a crisis, if any, they help to start up the economy ${ }^{2}$. All the three abovementioned functions include the historically oldest fiscal function, which primarily ensures fulfilling the public budget.

\section{Distribution of the $\mathrm{CZ}$ tax mix}

So as to fulfil the public budgets, national economies do not use only one tax, but several taxes, which are mutually interconnected, whereby creating so-called tax system ${ }^{3}$. The tax system is a set of all taxes which are levied at the specific territory, as a rule, in a state. Each tax has its positive and negative aspects. Its negative impacts on the economic processes are partially compensated for within the integrated tax system, which in turn fulfils its functions in the fiscal policy.

Tax systems are dependent on a number of factors ${ }^{4}$, which affect in mutual circumstances fulfilment of the basic principles and functions of taxes. The structure as well as amount of taxes is primarily subject to economic factors, such as the economic growth, inflation rate, the extent of engagement of the economy in the international trade, sector and geographic structure as well as the workforce structure. The sector structure in connection with the extent of concentration of the economy, i.e. the proportion of corporations (in Czech laws, the term legal person is used) and independent entrepreneurs, i.e. natural persons carrying on business, substantially affects the amount of tax income. With a larger concentration of companies, the relative proportion of employees when compared to independent entrepreneurs is growing. Taxation of employees is less demanding than taxation of independent entrepreneurs, since employment tax is withheld by the employer and employees have no possibility to influence a reduction of the tax base. The state, which has a high proportion in small entrepreneurs, should, in development of the tax system, emphasise more indirect taxes and endeavour so that its proportion would be as large as possible.

The significant feature of each modern tax system is distribution of taxation mix, i.e. position of the individually applied taxes and quasi-taxes. In 1993, the most significant transformation of the tax system in the Czech Republic took place, which included establishing an indirect taxation in the form of the value added tax and two direct income taxes. The social security

\footnotetext{
${ }^{2}$ This function was considerably underestimated in the Czech Republic. Between 2004 and 2007, when our economy was booming, the state budget should have shown a surplus and a "reserve cushion" could have been created, which could be used at present, at the time of crisis. However, public finances showed a deficit, besides others, as a result of "populist" expenditures.

${ }^{3}$ VANČUROVÁ, A. a kol. Daňový systém ČR 2008 aneb učebnice daňového práva. Prague: VOX, 2008. ISBN 978-80-86324-72-2. p. 34.

${ }^{4}$ KUBÁTOVÁ, K. Daňová teorie a politika. Prague: ASPI, 2006. ISBN 80-7357-205-2. p. 150.
} 
has again become a part of the income part of the state budget. A gradual reduction in income taxation (above all, corporations) and a concurrent progression of the proportion of indirect taxes was presented as a long-term strategy of the tax policy. The development of the tax mix in the Czech Republic is presented in the following tables and graphs. The development is shown both in the absolute terms of the individual types of tax incomes in the sector of government institutions between 1996 and 2008, and in the percentage figures.

Table No. 1: Tax income in the government institutions sector between 1996 - 2008 (in $C Z K$ bn)

\begin{tabular}{|l|c|c|c|c|c|c|c|c|c|c|c|c|c|}
\hline Tax income & $\mathbf{1 9 9 6}$ & $\mathbf{1 9 9 7}$ & $\mathbf{1 9 9 8}$ & $\mathbf{1 9 9 9}$ & $\mathbf{2 0 0 0}$ & $\mathbf{2 0 0 1}$ & $\mathbf{2 0 0 2}$ & $\mathbf{2 0 0 3}$ & $\mathbf{2 0 0 4}$ & $\mathbf{2 0 0 5}$ & $\mathbf{2 0 0 6}$ & $\mathbf{2 0 0 7}$ & $\mathbf{2 0 0 8}$ \\
\hline $\begin{array}{l}\text { Tax on } \\
\text { production and } \\
\text { import* }\end{array}$ & 203.6 & 208.8 & 218.9 & 240.3 & 247.9 & 258 & 266.7 & 285.4 & 325.3 & 342.3 & 352.4 & 394.4 & 405.6 \\
\hline $\begin{array}{l}\text { Social } \\
\text { allowances** }\end{array}$ & 239.8 & 264.8 & 281.7 & 292.7 & 312 & 335 & 367.4 & 388.9 & 452.8 & 482.1 & 524.8 & 576.7 & 599.2 \\
\hline $\begin{array}{l}\text { Income } \\
\text { tax/natural } \\
\text { persons }\end{array}$ & 80.2 & 87.4 & 94 & 93 & 99.7 & 106.2 & 114.9 & 125.5 & 135 & 136.4 & 136.6 & 153.4 & 148.8 \\
\hline $\begin{array}{l}\text { Income } \\
\text { tax/legal } \\
\text { persons }\end{array}$ & 56.5 & 69.4 & 67.5 & 79.5 & 76.2 & 96.3 & 105.7 & 117.8 & 131.7 & 133.5 & 154.8 & 176.5 & 163.8 \\
\hline $\begin{array}{l}\text { Capital } \\
\text { taxes*** }\end{array}$ & 0.5 & 0.6 & 0.6 & 0.5 & 0.6 & 0.7 & 0.7 & 0.9 & 0.6 & 0.7 & 0.8 & 0.5 & 0.4 \\
\hline Total & $\mathbf{5 8 0 . 6}$ & $\mathbf{6 3 1 . 0}$ & $\mathbf{6 6 2 . 7}$ & $\mathbf{7 0 6 . 0}$ & $\mathbf{7 3 6 . 4}$ & $\mathbf{7 9 6 . 2}$ & $\mathbf{8 5 5 . 4}$ & $\mathbf{9 1 8 . 5}$ & $\mathbf{1 , 0 4 5 . 4}$ & $\mathbf{1 , 0 9 5 . 0}$ & $\mathbf{1 , 1 6 9 . 4}$ & $\mathbf{1 , 3 0 1 . 5}$ & $\mathbf{1 , 3 1 7 . 8}$ \\
\hline
\end{tabular}

Note: All details are arranged according to ESA 95 methodology (Eurostat)

* Mandatory payments, which production companies must pay to the state and which concern production activities or imports or using production factors (e.g. VAT, excise tax, etc.).

** Mandatory and optional payments of employers (in favour of its employees), employees, independent entrepreneurs and self-payers to social security authorities and health insurance companies. Since 2004, including insurance premium of so-called state insured persons (the regulation does not affect the deficit, because expenditures are increased in the same amount).

*** Irregular payments in favour of government institutions of the value of property, assets or net property of the unit (e.g. donation, inheritance tax).

Source: own calculations from the Ministry of Finance of the Czech Republic data

Graph No. 1: Tax income in the government institutions sector between 1996 - 2008 (in $C Z K$ bn)

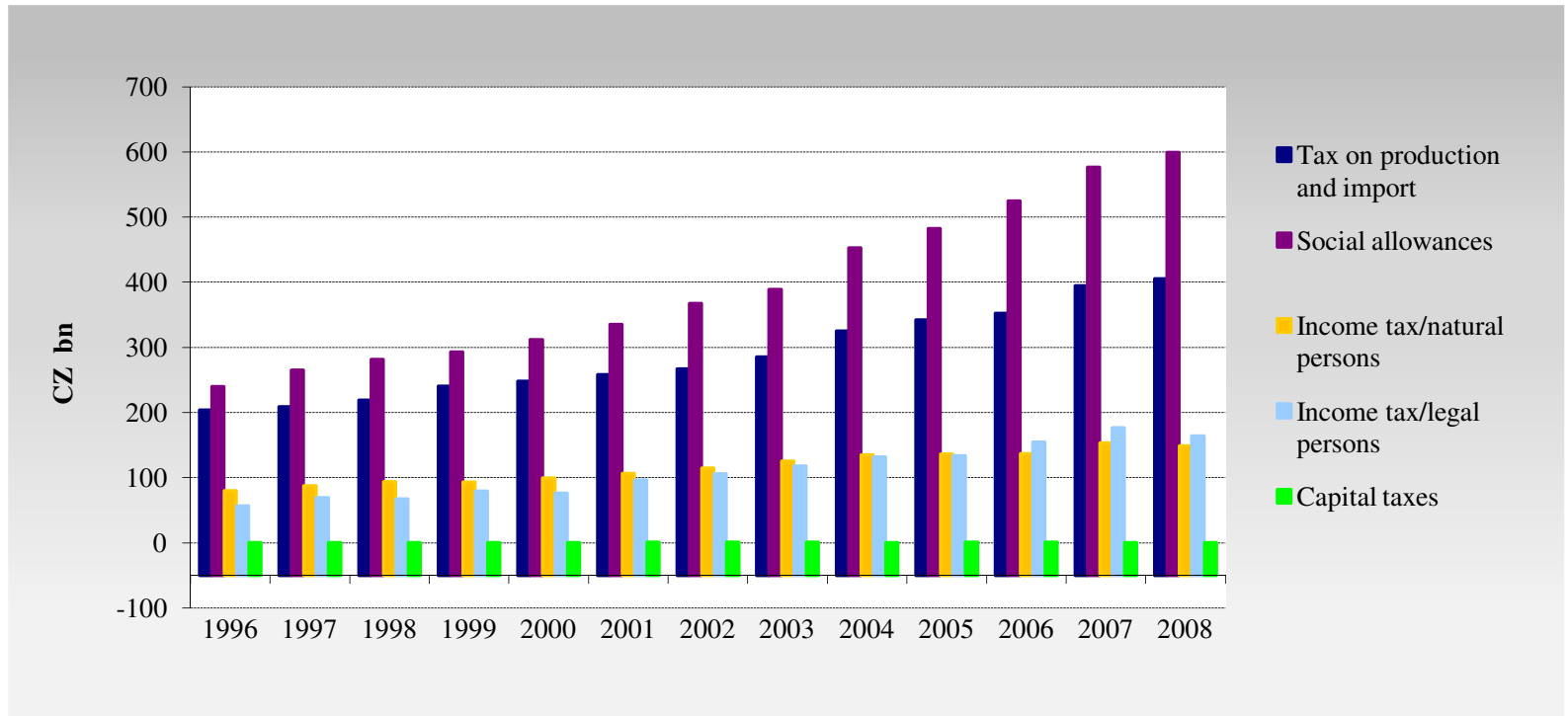

Source: author's calculations from the Ministry of Finance of the Czech Republic data 
Table No. 2: Tax income in the government institutions sector between 1996 - 2008 (in \% of the total income of taxes)

\begin{tabular}{|l|r|r|r|r|r|r|r|r|r|r|r|r|r|}
\hline Tax income & $\mathbf{1 9 9 6}$ & $\mathbf{1 9 9 7}$ & $\mathbf{1 9 9 8}$ & $\mathbf{1 9 9 9}$ & $\mathbf{2 0 0 0}$ & $\mathbf{2 0 0 1}$ & $\mathbf{2 0 0 2}$ & $\mathbf{2 0 0 3}$ & $\mathbf{2 0 0 4}$ & $\mathbf{2 0 0 5}$ & $\mathbf{2 0 0 6}$ & $\mathbf{2 0 0 7}$ & $\mathbf{2 0 0 8}$ \\
\hline $\begin{array}{l}\text { Tax on production } \\
\text { and import }\end{array}$ & 35.1 & 33.1 & 33.0 & 34.0 & 33.7 & 32.4 & 31.2 & 31.1 & 31.1 & 31.3 & 30.1 & 30.3 & 30.8 \\
\hline Social allowances & 41.3 & 42.0 & 42.5 & 41.5 & 42.4 & 42.1 & 43.0 & 42.3 & 43.3 & 44.0 & 44.9 & 44.3 & 45.5 \\
\hline $\begin{array}{l}\text { Income tax/natural } \\
\text { persons }\end{array}$ & 13.8 & 13.9 & 14.2 & 13.2 & 13.5 & 13.3 & 13.4 & 13.7 & 12.9 & 12.5 & 11.7 & 11.8 & 11.3 \\
\hline $\begin{array}{l}\text { Income tax/legal } \\
\text { persons }\end{array}$ & 9.7 & 11.0 & 10.2 & 11.3 & 10.3 & 12.1 & 12.4 & 12.8 & 12.6 & 12.2 & 13.2 & 13.6 & 12.4 \\
\hline Capital taxes & 0.1 & 0.1 & 0.1 & 0.1 & 0.1 & 0.1 & 0.1 & 0.1 & 0.1 & 0.1 & 0.1 & 0.0 & 0.0 \\
\hline Total & $\mathbf{1 0 0 . 0}$ & $\mathbf{1 0 0 . 0}$ & $\mathbf{1 0 0 . 0}$ & $\mathbf{1 0 0 . 0}$ & $\mathbf{1 0 0 . 0}$ & $\mathbf{1 0 0 . 0}$ & $\mathbf{1 0 0 . 0}$ & $\mathbf{1 0 0 . 0}$ & $\mathbf{1 0 0 . 0}$ & $\mathbf{1 0 0 . 0}$ & $\mathbf{1 0 0 . 0}$ & $\mathbf{1 0 0 . 0}$ & $\mathbf{1 0 0 . 0}$ \\
\hline
\end{tabular}

Source: own calculations from the Ministry of Finance of the Czech Republic data

Graph No. 2: Tax income in the government institutions sector between 1996 - 2008 (in \% of the total income of taxes)

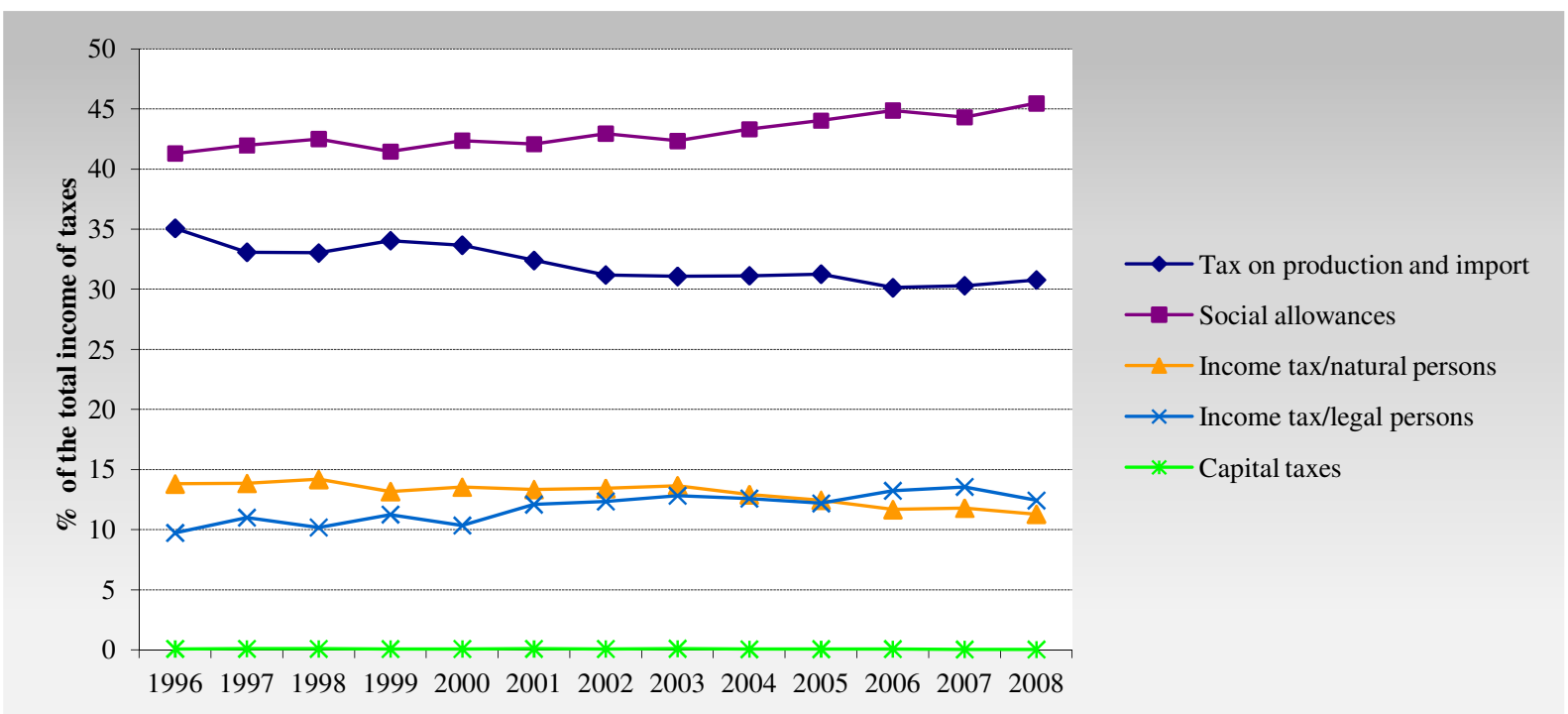

Source: author's calculations from the Ministry of Finance of the Czech Republic data

As the graphs above indicate all sorts of tax incomes are growing. An increase in the proportion of indirect taxes is a positive phenomenon, but a growth in the social security is an undesired trend with respect to the unresolved pension reform. However, the income of the legal persons' taxation has gradually become the third most important income of public budgets, when since 2006 they gave exceeded the income of natural persons' taxes.

\section{Comparison of corporate taxation in the Czech Republic and EU}

The historically newest type of taxation in tax systems includes the corporate taxation, which follows up the medieval revenue tax. At present, the tax base is subject to taxation, which is an accounting profit/loss of a company adjusted according to the applicable tax legislation. Variable terminology is used in the literature for this tax, for instance, an income tax of companies, corporate tax, tax on corporate profit ${ }^{5}$. As notes Kubátová ${ }^{6}$ in different countries,

\footnotetext{
${ }^{5}$ Each state has its identification of types of corporations. In the Czech Republic, we tend to speak of a firm, plant and in the tax laws of so-called legal persons, which are commonly divided into a joint stock company, limited liability company, public company, a cooperative, etc. The rights and obligations of a "corporation" are stipulated by a law, which is the Commercial Code in our country.

${ }^{6}$ KUBÁTOVÁ, K. Daňová teorie a politika. Prague: ASPI, 2006. ISBN 80-7357-205-2. p. 187.
} 
a differential tax policy is used with respect to these business units, which results in ambiguity related also to the statutory regulation of incomes of different types of companies. In some countries, a specific regulation regarding taxation of joint stock companies is in force, which is different in the manner of taxation of other legal forms. The size of the business unit is another criterion, which is a reason of a different taxation terminology of companies and which is applied in some countries.

Enlargement of the European Union and the globalisation process substantially affect also taxation systems and the fiscal policy in the individual countries ${ }^{7}$. Direct taxation, which includes also income tax of corporations, falls under the competence of national authorities of countries and the individual countries, having a need to keep cohesiveness of tax systems, may consequently apply their own tax policy. The European Union does not intend to unify national tax systems; however it tries hard to achieve mutual comparability, which would be based on the previously accepted and introduced treaties in the $\mathrm{EU}^{8}$. The Treaty on European Community ${ }^{9}$ contains the requirement of so-called tax neutrality ${ }^{10}$, expressed in Art. 90 et seq. The major mission of the European Union tax policy is to ensure smooth operation of the internal market, particularly free move of goods, services and capital, not to unify national tax systems, but ensure equal conditions on the European market, remove tax obstacles of international business, fights against harmful tax competition ${ }^{11}$ and prosecute tax frauds. The tax policy should also support other general goals of the EU, which include the economic growth, employment and competitiveness, as well as the environmental and energy goals. Discussions have been held in the EU for several years concerning harmonisation of direct taxation, particularly corporations, and in connection with the abovementioned tax neutrality. In spite of that, taxation of companies with respect to the mobility of its base remains the subject matter of sharp tax competition ${ }^{12}$ among the individual states of the European

7 REDOANO, M. Fiscal Interactions Among European Countries. Does the EU Matter? [Online], [cit. 10. 9. 2010]. Url: http://www2.warwick.ac.uk/fac/soc/csgr/research/abstracts/222/

${ }^{8}$ A tax policy belongs among policies with shared competencies. The Member States may issue their own legislation unless a joint European regulations exist here, or, where appropriate, as an addendum thereto. The tax practice is more or lass a sum of factually independent policies of the individual EU Member States. In different periods, increased efforts occur (for instance, on the entry of the European Commission led by R. Prodi) to harmonise European taxes, however these attempts have been unsuccessful so far, because the Member States do not demonstrate enough willingness to delegate powers to the EU authorities.

${ }^{9}$ The Consolidated version of the Treaty on European Union and Treaty on Operation of European Union. In: Official Bulletin of European Union. 2008/C115/01. ISSN 1725-5163.

${ }^{10}$ Tax neutrality is understood so that decisions of companies regarding location of investments should not be influenced by the tax system of the Member State. Neutrality is sometimes understood also in connection to the type of investment - i.e. certain sectors, forms of business or resources of funding of investments should not be preferred. In addition, the international tax neutrality presumes neutrality with respect to international investments.

${ }^{11}$ In 1997, the EU Council adopted "The Code of Conduct for Business Taxation" with a view to eliminating tax competition between the Member States. The Code is not legally binding but has a political significance. It should lead to removal of statutory provisions enabling advantaged taxation of foreign companies without these companies having to carry on any business activity in the particular country, i.e. limitation of only harmful consequences of tax competition.

${ }^{12}$ According to OECD, there exists "regular" and "unfair" tax competition. This organisation attempts to make sure that no obstacles as to the international exchange of information required for due tax determination would not exist, i.e. OECD does not have any objections to tax competition but it is intended that it would be possible to duly and effectively levy taxes. According to the degree of cooperation in exchange of tax information, 3 groups of countries are distinguished, which are placed on white, gray and black list. The Czech Republic is placed on the white list, which contains fully cooperating countries. 
Union $^{13}$. For companies investing their capital, quality and the specific form of tax environment is one of the most important criteria, which have substantial effects on selection of the right place of their business. A question is what variable comparison to use when taking a decision concerning a location of the investment.

\subsection{Statutory taxation}

In the Czech Republic, the income tax has showed a gradual fall, including the income tax of legal persons (corporations). Changes in direct taxation of companies were not directly caused by harmonisation of this tax by the European Union, but the intention of our economy was not to discourage incoming foreign capital by an unfavourable tax system. The development of taxation of corporate incomes, i.e. a gradual reduction of the rate for legal persons, is shown in Graph No.3 below.

Graph No. 3: Development of the statutory rate of income tax for legal persons in CZ between 1993 - 2010

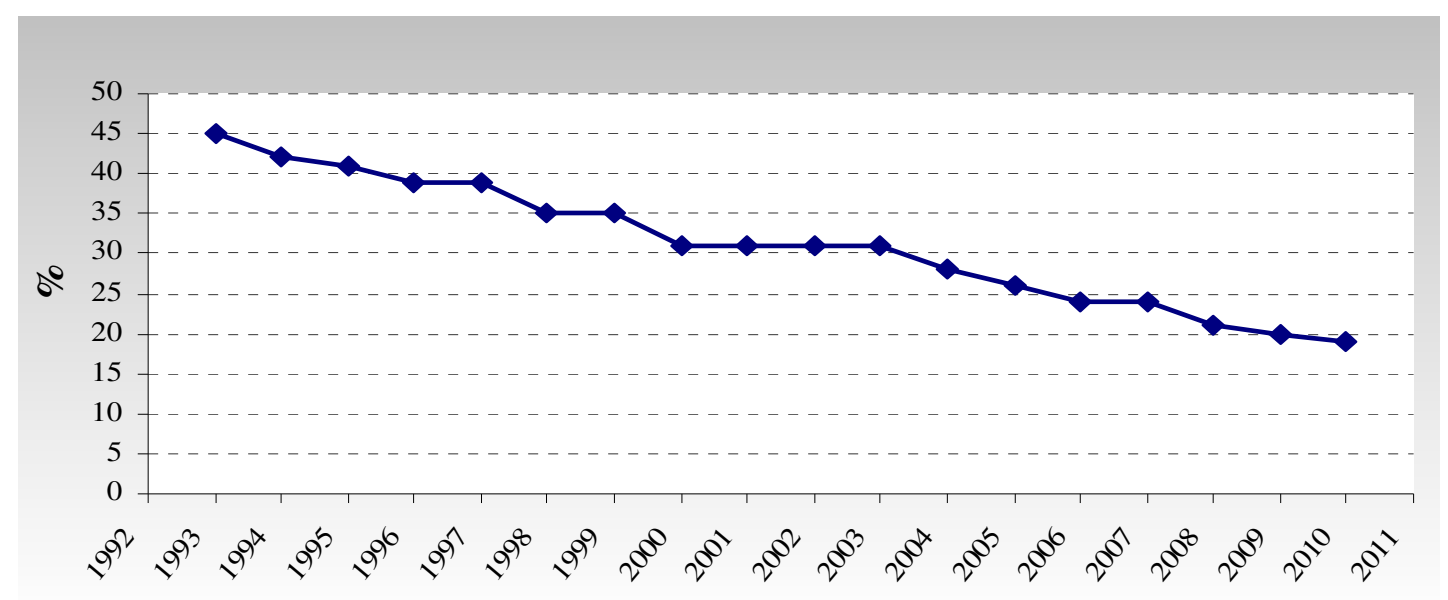

Source: author

The level of taxation is considered as one of the substantial factors. A gradual decline in the income tax of corporations has occurred in Europe as well. This fact affects behaviour of advanced economies, which are forced to increase or at least maintain competitiveness of their country in the fight for foreign investors with the adjacent Central European or East European countries. In this respect, the efforts to maintain significant domestic companies on its territory and prevent from their leave to more favourable destinations in terms of tax and to the countries with cheap labour force, which are also the East European countries, has become the strategy of the West European countries. On the contrary, the East European countries attempt to attract these foreign companies to conduct business in their area. In 1993, the European Union only consisted of 15 member states and their average income tax rate of legal persons in this period amounted to $38 \%$. Fifteen years later, the EU has extended by 10 more countries and concurrently the average corporate rate has fallen nearly by one third to $23.2 \%$. The development of corporate income tax rates in the EU is shown in Graph No.4.

\footnotetext{
${ }^{13}$ BALDWIN, R. E., KRUGMAN, P.: Agglomeration, Integration and Tax Harmonization, 2002. [Online], [cit. 10. 9. 2010]. Url: http://www.sciencedirect.com/science/article/B6V64-48M7XY51/2/f75e1f092b9552c7b18af65fee07844f.
} 


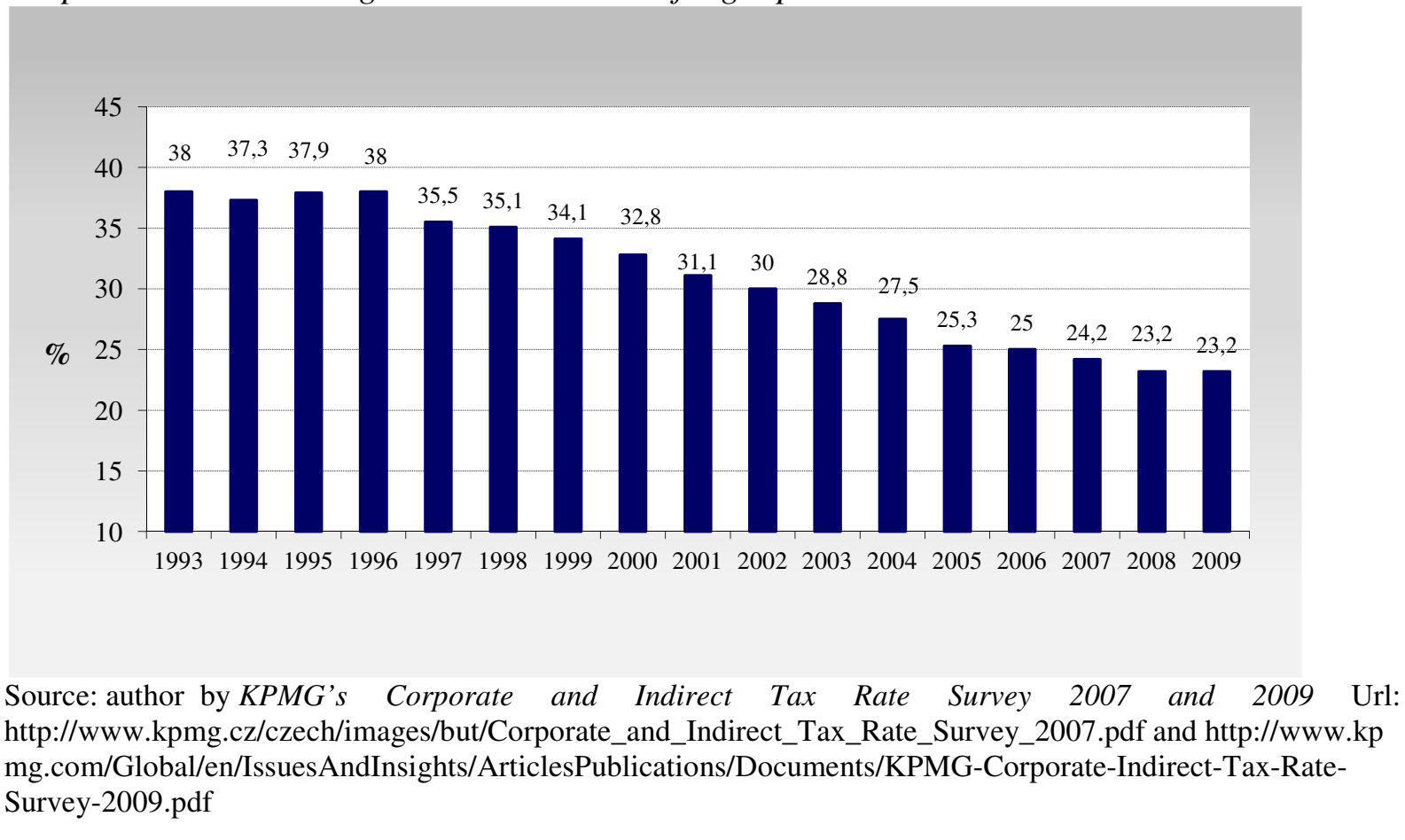

In the graphs above, we can see the identical trend of reduction of statutory rates of corporate taxes, while the fall in the Czech Republic was far greater (from $45 \%$ in 1993 to $20 \%$ in 2009) than in the European Union, the fall in the average rate was not that dramatic (from $38 \%$ in 1993 to $23.2 \%$ in 2009).

The simplest alternative is the comparison of statutory corporate rates of income taxes. For its simplicity and easy availability of data, this comparison has become the most commonly applied. The following graph shows the statutory rate of income tax of corporations in the individual countries of the European Union in 2010. It may be deduced from it that the Czech Republic with the rate of $19 \%$ amounts above the EU-27 average rate, which amounted to $23.2 \%$ in 2010. The countries with the highest corporate rate over $30 \%$ include Malta, France, Belgium and Italy; on the contrary, the countries whose rate amounts below $20 \%$ frontier include the Czech Republic, Poland and Slovakia with the rate of $19 \%$; another group includes Romania, Luxembourg and Ireland and the lowest rate of $10 \%$ can be found in two EU countries, i.e. Bulgaria and Cyprus. 
Graph No. 5: Statutory income tax rates of corporations in the individual EU ${ }^{14}$ countries in 2010

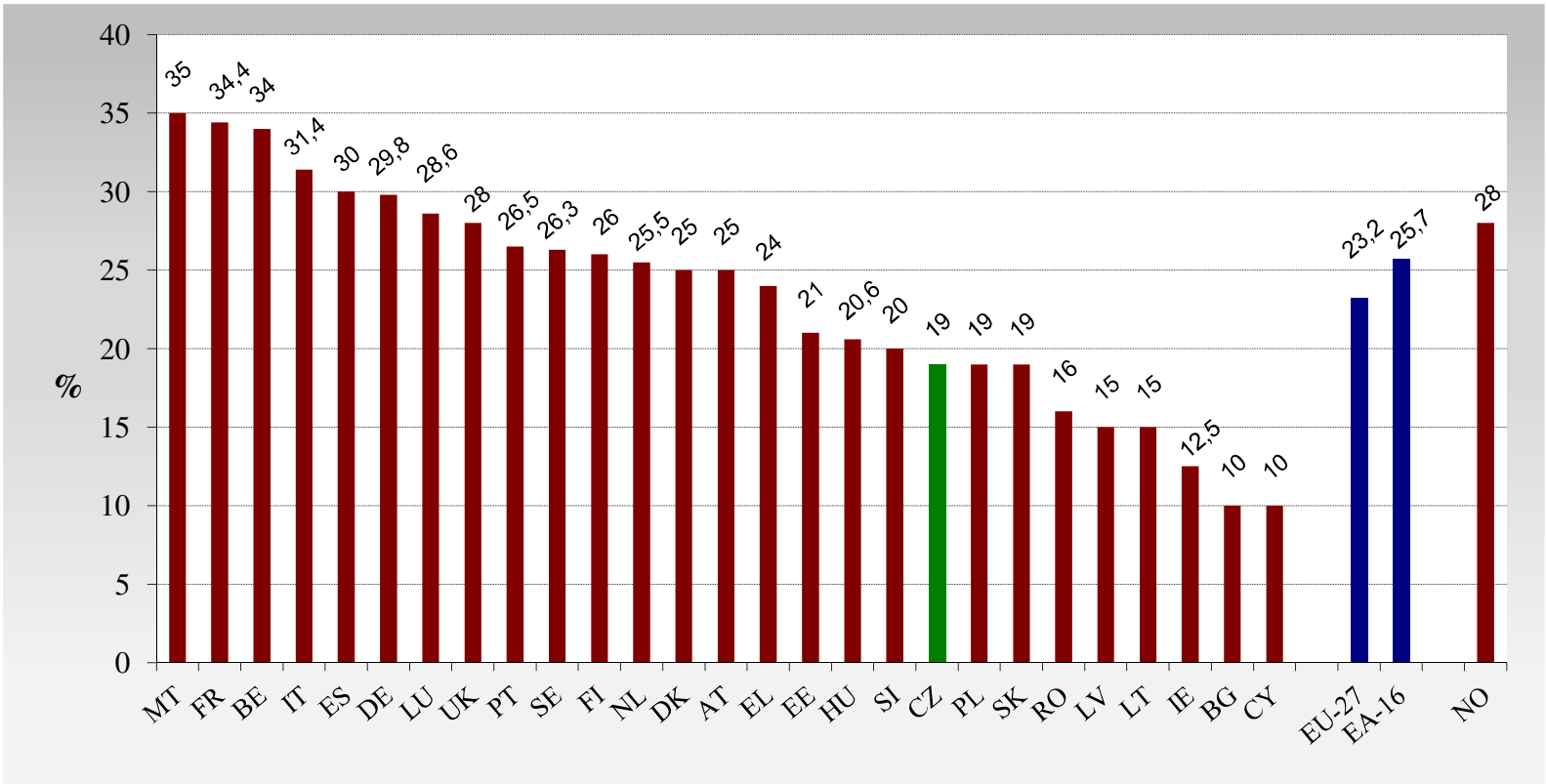

Source: Taxation trends in European Union (Main results). Luxembourg: Publications Office of the European Union, 2010. ISBN 978-92-79-15802-5

The statutory income tax rates may include not only so-called nominal tax rates, but also tentative or permanent additional taxes and reliefs, which requires sufficient attention. In addition, the construction of tax is different in the individual countries, because a considerable number of these countries levy corporate tax at different levels of the state administration.

Different rules for setting corporate tax base and its amount, which are caused by individual tax legislations in the particular countries, are also a substantial limitation for objective comparison of the burden of companies by statutory income tax rates in those countries. Consequently, for the purposes of the reciprocal international comparison, statutory tax rates are not quite an appropriate and objective indicator.

In this connection, it is important to note that the proportion of corporate tax incomes in the total incomes from taxes has been growing in long term in spite of a fall in the statutory tax rates of legal persons, which is caused by tax competition. This fact is a result of extension of tax bases, progress of corporate business and other factors. The development of the tax from companies' profit in the total tax income is presented in the following table and graph.

Table No. 3: The proportion of the tax on corporations' profit in the total tax incomes in the individual EU countries between 1998 - 2008

\begin{tabular}{|c|c|c|c|c|c|c|c|c|c|c|c|}
\hline Country & 1998 & 1999 & 2000 & 2001 & 2002 & 2003 & 2004 & 2005 & 2006 & 2007 & 2008 \\
\hline $\mathrm{AT}$ & 31,0 & 30,3 & 30,6 & 33,4 & 31,7 & 31,5 & 31,3 & 30,5 & 31,0 & 32,1 & 32,8 \\
\hline $\mathrm{BE}$ & 39,0 & 38,2 & 38,9 & 39,3 & 38,9 & 38,4 & 38,9 & 39,2 & 38,8 & 38,7 & 38,9 \\
\hline BG & 27,8 & 25,2 & 21,4 & 24,5 & 21,6 & 20,7 & 18,1 & 16,9 & 17,9 & 20,9 & 21,0 \\
\hline $\mathrm{CY}$ & 35,3 & 38,2 & 36,7 & 36,2 & 35,8 & 29,2 & 26,0 & 28,6 & 29,6 & 33,6 & 32,9 \\
\hline$C Z$ & 25,0 & 24,9 & 24,6 & 26,0 & 26,2 & 27,0 & 25,7 & 24,7 & 25,0 & 25,4 & 23,8 \\
\hline
\end{tabular}

\footnotetext{
${ }^{14}$ MT - Malta, FR - France, BE - Belgium, IT - Italy, ES - Spain, DE - Germany, LV - Latvia, UK - Great Britain, PT - Portugal, SE - Sweden, FI - Finland, NL - Netherlands, DK - Denmark, EL - Greece, AT - Austria, HU - Hungary, EE - Estonia, SI - Slovenia, CZ - Czech Republic, LT - Lithuania, PL - Poland, SK - Slovakia, RO - Romania, LU - Luxembourg, IE - Ireland, BG - Bulgaria, CY - Cyprus, NO - Norway (not an EU Member State), EA-16 - Euro Area (16 member countries, membership as from 1.1.2009).
} 


\begin{tabular}{|c|c|c|c|c|c|c|c|c|c|c|c|}
\hline $\mathrm{DE}$ & 28,0 & 28,6 & 29,8 & 27,6 & 27,2 & 26,7 & 26,3 & 26,7 & 27,9 & 28,7 & 29,1 \\
\hline DK & 61,0 & 60,6 & 61,8 & 60,9 & 61,2 & 61,6 & 62,0 & 62,8 & 61,8 & 61,5 & 62,3 \\
\hline $\mathrm{EE}$ & 30,5 & 30,0 & 25,0 & 23,9 & 24,3 & 26,2 & 26,0 & 22,8 & 23,0 & 23,7 & 24,7 \\
\hline EL & 27,0 & 27,2 & 28,8 & 26,6 & 26,2 & 24,9 & 26,1 & 27,3 & 25,7 & 25,0 & 24,5 \\
\hline ES & 31,3 & 30,8 & 31,1 & 31,0 & 31,9 & 30,9 & 30,7 & 32,0 & 33,4 & 36,1 & 33,9 \\
\hline FI & 41,3 & 40,9 & 45,3 & 43,0 & 42,9 & 41,0 & 41,0 & 40,6 & 40,3 & 41,4 & 41,4 \\
\hline FR & 26,8 & 27,7 & 28,3 & 28,9 & 27,3 & 26,5 & 26,9 & 27,0 & 27,7 & 27,5 & 27,7 \\
\hline $\mathrm{HU}$ & 23,2 & 24,3 & 24,9 & 26,4 & 26,7 & 25,3 & 24,1 & 24,3 & 25,3 & 25,7 & 26,3 \\
\hline $\mathrm{IE}$ & 43,4 & 43,6 & 42,8 & 42,9 & 40,8 & 41,1 & 41,1 & 40,1 & 41,0 & 40,9 & 39,3 \\
\hline IT & 34,5 & 35,4 & 34,8 & 35,7 & 34,5 & 35,6 & 34,3 & 33,2 & 34,3 & 35,1 & 36,0 \\
\hline LT & 28,3 & 28,8 & 28,1 & 27,3 & 26,4 & 28,3 & 30,8 & 31,6 & 32,6 & 31,0 & 31,0 \\
\hline $\mathrm{LU}$ & 40,9 & 39,0 & 38,4 & 38,4 & 39,2 & 38,8 & 35,2 & 36,6 & 36,7 & 36,9 & 38,0 \\
\hline $\mathrm{LV}$ & 23,7 & 24,0 & 24,7 & 26,5 & 27,5 & 26,5 & 27,7 & 27,2 & 27,9 & 30,2 & 33,5 \\
\hline MT & 31,3 & 32,1 & 32,7 & 33,5 & 36,1 & 38,2 & 34,6 & 35,5 & 36,3 & 39,2 & 38,5 \\
\hline $\mathrm{NL}$ & 30,9 & 30,0 & 30,0 & 30,6 & 31,3 & 29,3 & 28,6 & 31,2 & 30,5 & 31,6 & 30,5 \\
\hline PL & 30,7 & 22,2 & 22,1 & 20,7 & 21,2 & 20,5 & 20,3 & 21,3 & 22,2 & 24,6 & 25,2 \\
\hline PT & 26,9 & 27,6 & 28,9 & 27,9 & 27,0 & 25,0 & 25,1 & 24,2 & 24,6 & 26,5 & 27,1 \\
\hline $\mathrm{RO}$ & 28,9 & 25,1 & 23,1 & 22,2 & 20,5 & 21,6 & 23,3 & 19,2 & 21,1 & 23,1 & 24,0 \\
\hline $\mathrm{SE}$ & 41,0 & 42,2 & 42,6 & 39,3 & 36,8 & 37,9 & 39,3 & 40,2 & 40,5 & 39,4 & 37,0 \\
\hline SI & 19,8 & 19,6 & 19,8 & 20,2 & 20,7 & 20,9 & 21,6 & 22,5 & 23,8 & 24,3 & 24,1 \\
\hline SK & 24,5 & 25,5 & 21,9 & 22,6 & 21,3 & 21,7 & 19,4 & 19,2 & 20,7 & 21,0 & 22,1 \\
\hline UK & 45,6 & 45,0 & 45,4 & 46,1 & 44,9 & 43,7 & 43,7 & 45,4 & 46,5 & 46,4 & 48,8 \\
\hline
\end{tabular}

Source: Taxation trends in European Union. Luxembourg: Publications Office of the European Union, 2010. ISBN 978-92-79-15801-8

Graph No. 6: The proportion of the tax on companies' profit in the total tax incomes between 1998 - 2087

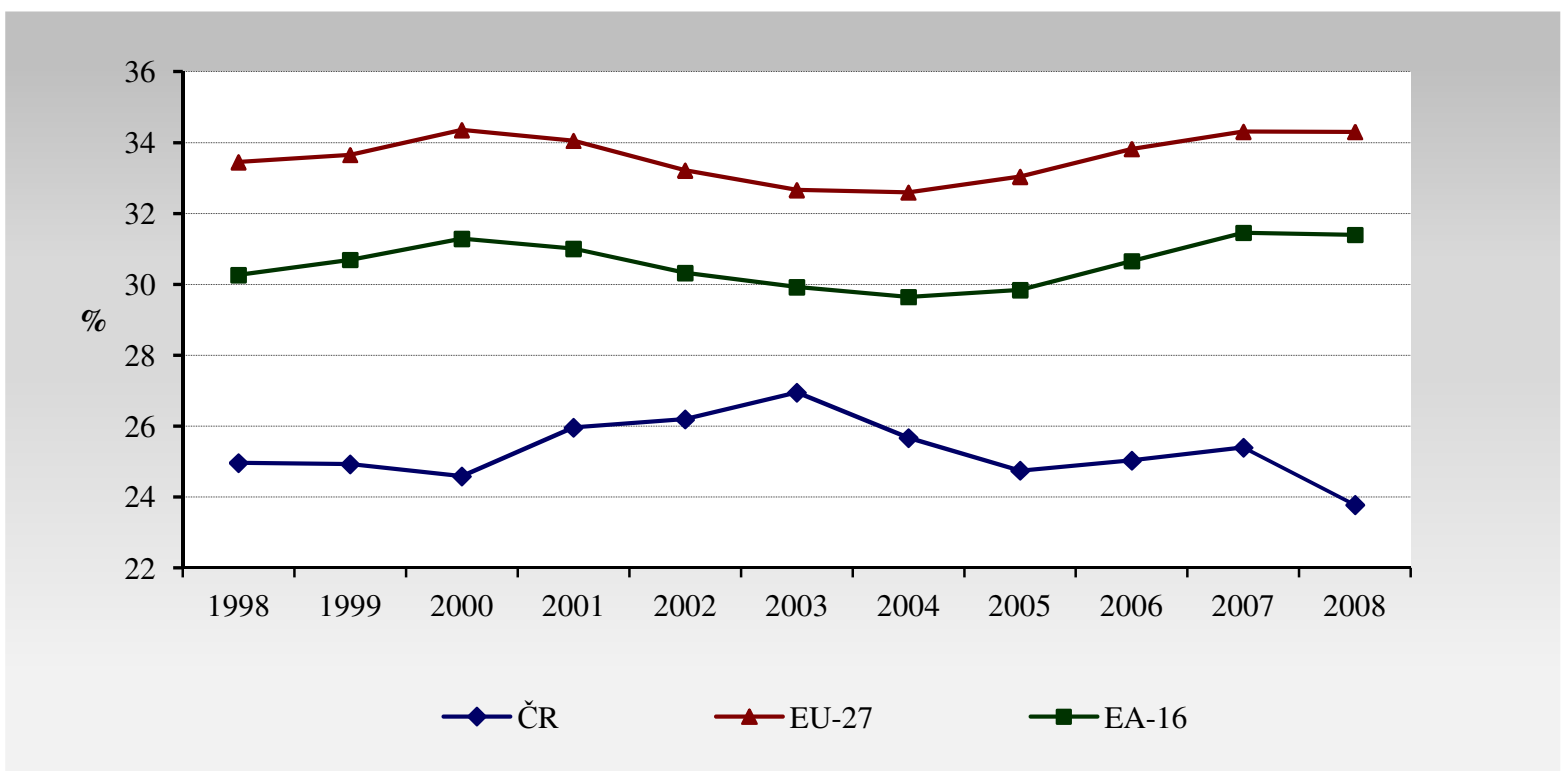

Source: author by Taxation trends in European Union. Luxembourg: Publications Office of the European Union, 2010. ISBN 978-92-79-15801-8

\subsection{Implicit taxation}

Implicit corporate tax rate appears to be an appropriate measure of comparison of effective taxation of corporations, which are tax rates where consideration is taken not only of the amount of the statutory tax rates from corporations' rates, but also other aspects of taxation systems determining the total amount of effectively paid taxes. Therefore, account is taken of the tax base and the method (if any) by which the systems of corporate and personal income taxes are integrated.

So as to determine the average effective rate, certain simplifications must be applied, whereas each method of simplifications shows its pros and cons. In principle, there exist three methods 
of determination of effective tax rates. These methods are coined as methods of backward macroeconomic view, backward microeconomic view and forward microeconomic view. The differences between macroeconomic and microeconomic approaches are determined by the applied data. The macroeconomic approach calculates effective tax rates of aggregated macroeconomic data contained in the national accounting of the individual states. On the contrary, microeconomic approaches calculate these rates from the financial statements of the individual companies containing either empirical data or data concerning the theoretical perspective. The differences between the approaches with backward and forward perspective are determined by the type of applied information. For estimation of tax burden of companies, approaches with backward view use ex-post data concerning the real life of companies, while the approaches with forward perspective use statutory characteristics of a tax system for determination of tax aspects concerning future business decisions of companies ${ }^{15}$.

The implicit corporate tax rate is calculated as a ratio of the aggregated income taxes or from profits paid by corporations to the value of tax base, which is the corresponding potentially taxable base including these aggregated values: net operating profit/loss of non-financial and financial corporations, the difference between the received and paid interest, rent of lands, income from property insurance and dividends distributed by companies operating in the particular state and credited to non-financial and financial corporations, households, independent entrepreneurs and non-profit institutions, state authorities and the rest of the world. The following graph represents the development of the implicit rate of tax from profit of companies between 1995 to 2008.

\section{Graph No. 7: The development of the implicit rate of tax on profit of companies between1995 - 2008}

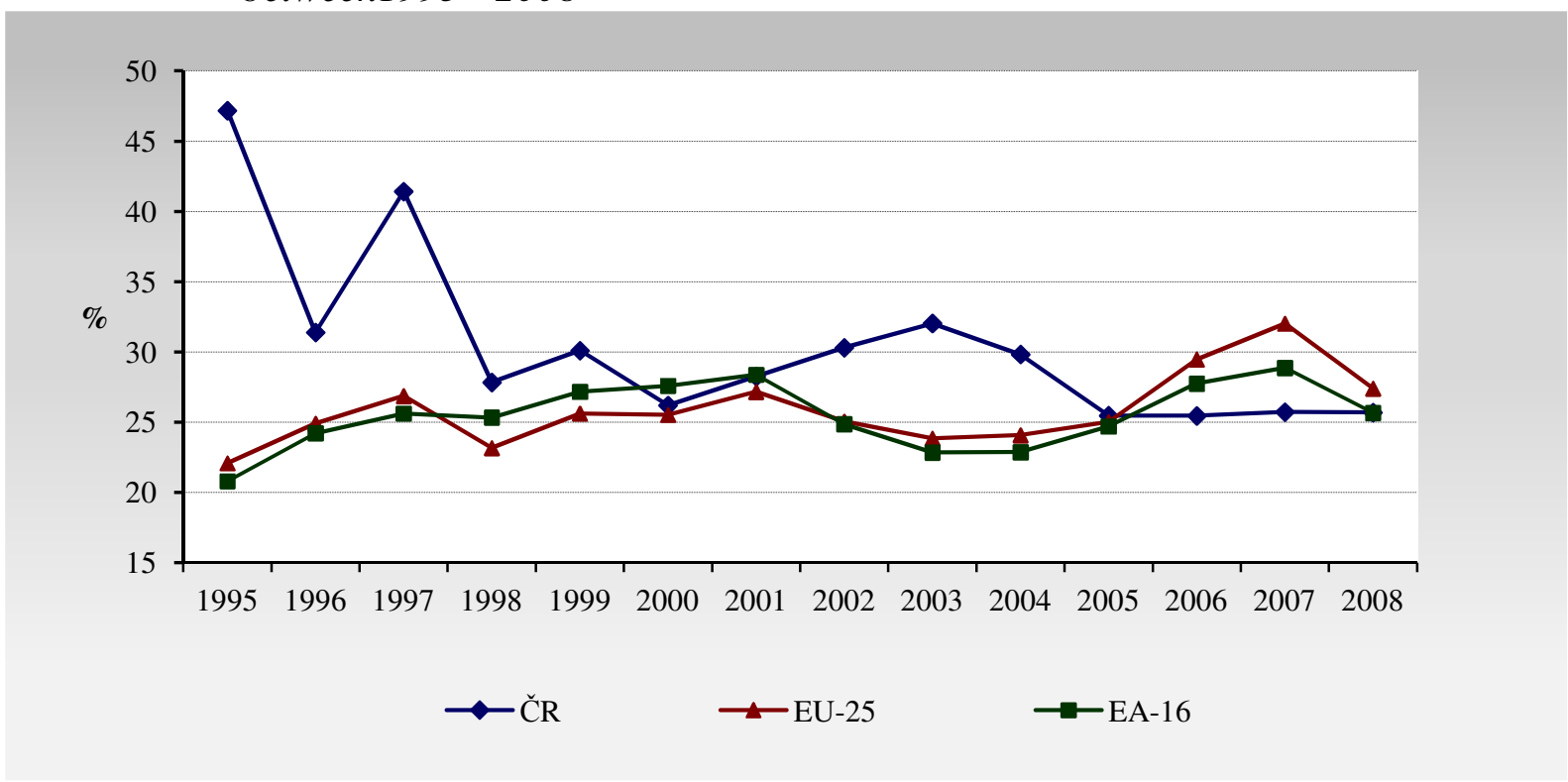

Note: data of EU-27 not available

Source: author by Taxation trends in European Union. Luxembourg: Publications Office of the European Union, 2010. ISBN 978-92-79-15801-8

As it has been indicated above, the implicit corporate tax rate is the tax rate which does not take into consideration only the statutory tax rate but also other aspects of the tax system

\footnotetext{
${ }^{15}$ BLECHOVÁ, B. Charakteristika př́stupů používaných v EU pro hodnocení efektivního daňového zatížení př́ijmů korporací. In. Theoretical and Practical Aspects of Public Finance. Prague: VŠE, 2008. ISBN 978-80245-1378-2.
} 
which determine the volume of effectively paid tax. According to these statistics, the general dramatic fall in the statutory rates is not accompanied by a fall in tax payments proportionally with GDP, as it is apparent in the following table and graph.

Table No. 4: The proportion of the tax on corporations' profits in GDP between 1998 - 2008

\begin{tabular}{|c|c|c|c|c|c|c|c|c|c|c|c|}
\hline Country & 1998 & 1999 & 2000 & 2001 & 2002 & 2003 & 2004 & 2005 & 2006 & 2007 & 2008 \\
\hline $\mathrm{AT}$ & 5,3 & 4,5 & 5,0 & 7,2 & 5,5 & 5,3 & 5,6 & 5,5 & 5,6 & 6,2 & 6,2 \\
\hline $\mathrm{BE}$ & 7,4 & 7,1 & 7,1 & 6,9 & 6,7 & 6,4 & 6,9 & 7,2 & 8,1 & 7,9 & 7,5 \\
\hline BG & 12,3 & 10,1 & 8,2 & 12,3 & 9,9 & 9,5 & 7,3 & 7,0 & 8,1 & 9,5 & 10,0 \\
\hline CY & 17,7 & 21,3 & 20,6 & 20,1 & 19,2 & 13,1 & 11,1 & 13,1 & 15,0 & 16,6 & 18,0 \\
\hline$C Z$ & 10,1 & 11,2 & 10,3 & 12,0 & 12,3 & 12,8 & 12,5 & 12,0 & 13,1 & 13,4 & 12,3 \\
\hline $\mathrm{DE}$ & 3,3 & 3,6 & 4,0 & 1,4 & 1,5 & 1,9 & 2,4 & 2,8 & 3,5 & 3,5 & 2,8 \\
\hline DK & 6,1 & 4,8 & 6,6 & 5,8 & 6,0 & 6,1 & 6,5 & 7,7 & 8,8 & 7,7 & 7,1 \\
\hline $\mathrm{EE}$ & 7,1 & 6,0 & 2,9 & 2,3 & 3,6 & 5,1 & 5,4 & 4,7 & 4,9 & 5,2 & 5,1 \\
\hline EL & 8,6 & 9,5 & 12,0 & 10,1 & 10,0 & 9,1 & 9,6 & 10,3 & 8,5 & 7,8 & 7,5 \\
\hline ES & 7,7 & 8,7 & 9,2 & 8,6 & 9,6 & 9,3 & 10,0 & 11,0 & 11,6 & 12,8 & 8,7 \\
\hline FI & 9,4 & 9,4 & 12,5 & 9,4 & 9,3 & 7,7 & 8,1 & 7,6 & 7,7 & 9,0 & 8,1 \\
\hline FR & 5,3 & 5,9 & 6,3 & 7,0 & 5,9 & 5,0 & 5,4 & 5,3 & 6,6 & 6,8 & 6,5 \\
\hline HU & 5,5 & 5,9 & 5,6 & 6,0 & 6,1 & 5,8 & 5,6 & 5,6 & 6,3 & 6,9 & 6,5 \\
\hline IE & 10,6 & 12,1 & 12,0 & 12,1 & 13,1 & 13,1 & 12,2 & 11,4 & 12,3 & 11,2 & 9,8 \\
\hline IT & 5,9 & 6,6 & 5,9 & 7,8 & 6,6 & 5,7 & 5,9 & 5,8 & 7,0 & 7,6 & 7,4 \\
\hline LT & 4,1 & 2,6 & 2,3 & 1,9 & 2,1 & 4,9 & 6,6 & 7,3 & 9,4 & 8,7 & 9,1 \\
\hline LU & 19,4 & 17,4 & 17,8 & 18,4 & 20,4 & 19,2 & 15,3 & 15,4 & 13,8 & 14,8 & 14,3 \\
\hline LV & 6,8 & 6,4 & 5,3 & 6,6 & 7,1 & 5,3 & 6,1 & 6,9 & 7,5 & 8,9 & 10,9 \\
\hline MT & 9,6 & 10,0 & 10,3 & 10,6 & 12,3 & 14,4 & 12,5 & 13,2 & 14,8 & 19,4 & 19,6 \\
\hline $\mathrm{NL}$ & 11,4 & 11,0 & 10,9 & 11,0 & 9,4 & 8,1 & 8,8 & 9,7 & 9,4 & 9,1 & 8,8 \\
\hline $\mathrm{PL}$ & 7,3 & 6,9 & 7,5 & 5,8 & 6,3 & 5,6 & 7,1 & 7,6 & 7,1 & 7,9 & 7,9 \\
\hline PT & 9,5 & 10,6 & 11,3 & 10,0 & 9,9 & 8,2 & 8,7 & 7,9 & 8,4 & 10,1 & 10,2 \\
\hline $\mathrm{RO}$ & 12,8 & 12,3 & 9,8 & 8,8 & 9,3 & 10,1 & 11,6 & 9,8 & 10,0 & 10,5 & 10,7 \\
\hline SE & 5,1 & 5,9 & 7,3 & 5,3 & 4,3 & 4,6 & 6,0 & 7,3 & 7,5 & 8,1 & 6,3 \\
\hline SI & 2,6 & 3,1 & 3,1 & 3,4 & 4,1 & 4,6 & 5,0 & 7,2 & 7,7 & 8,6 & 6,7 \\
\hline SK & 8,8 & 8,8 & 7,7 & 7,8 & 7,6 & 8,4 & 8,2 & 8,7 & 9,9 & 10,2 & 10,8 \\
\hline UK & 10,8 & 9,8 & 9,7 & 9,5 & 8,2 & 7,9 & 8,1 & 9,3 & 10,8 & 9,4 & 9,6 \\
\hline
\end{tabular}

Source: author by Taxation trends in European Union. Luxembourg: Publications Office of the European Union, 2010. ISBN 978-92-79-15801-8

Graph No. 8: The proportion of the tax on corporations' profits in GDP between 1998 - 2008

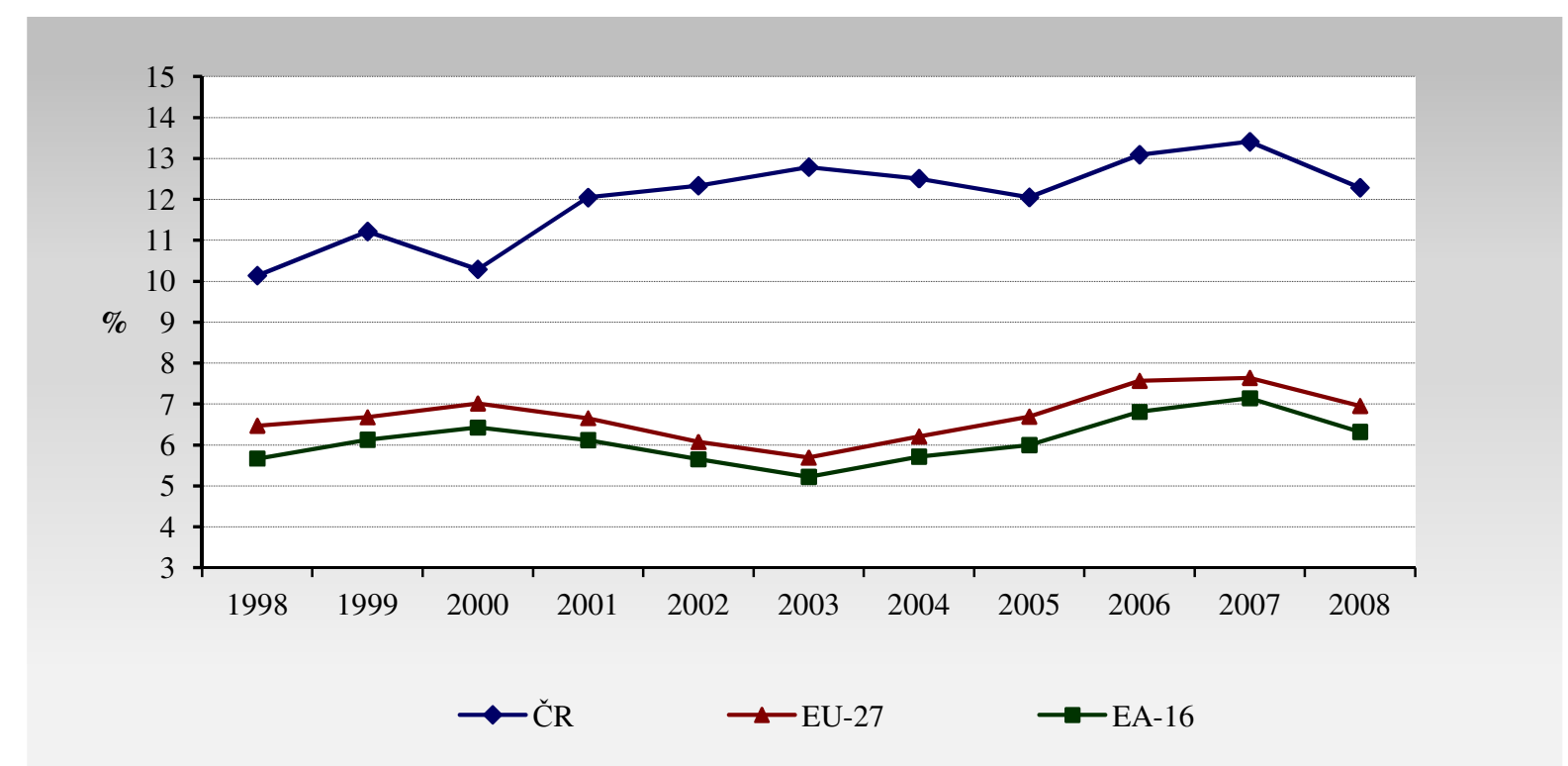

Source: author by Taxation trends in European Union. Luxembourg: Publications Office of the European Union, 2010. ISBN 978-92-79-15801-8 
In part, the reason rests in changes in profitability of taxpayers and in some countries also in the actual taxation system, where a fall in the rates is accompanied by extension of the tax base (e.g. tightening the rules of low capitalisation or extension of the tax depreciation period).

\section{Conclusion}

The significance of taxes, being income of public budgets, is indisputable in different concepts of the tax system. It depends on historical development of each country, but also on economic, political and, last but not least, philosophical opinions, how the structure and content of the tax system will be influenced. It is important for the state to pursue favourable tax policy, by which it would ensure support of all taxpayers, by which it would ensure competitiveness of the state and development of the society. Accordingly, the state's tax policy may not be separated from application of the state's economic policy and at the same time from the EU's tax policy ${ }^{16}$.

The taxation system is one of the critical factors in decisions taken by corporate management. As a result, the amount of taxation becomes a considerable perspective for selection of the place of business for foreign investors; with administrative complexity of taxes being another important criterion, and, last but not least, followed by their total number. Income taxes are an integral component of the taxation system in each modern market economy. In spite of that, a fall in the rate income tax of legal persons occurs worldwide. The hidden form of state grants of individual countries currently includes differences in the construction and principles of direct taxes. The individual countries attempt to attract new investors, who would support the economic growth of the whole country in a form of additional tax income as well as new job positions. On the other hand, foreign investors select a country with a low tax burden for their company. However, the problem may rest on the basis of which rates or variables the tax burden of corporations should be compared.

When companies make decisions about the location and implementation of their business activities, they find out the consequences of such activities. In most cases, they address the question by comparison of statutory corporate income tax rates. Nonetheless, this approach does not seem to be satisfactory with respect to complexity and diversity of elements creating of the national tax systems. The statutory tax rates may include besides the actual rate, socalled nominal tax rates, also effects of different tax surcharges or relieves, including tax rates, if any, concerning also local taxes. Their construction is not identical in different countries. A possibility to impartially compare the tax burden of corporations in different states by the statutory rates of income tax is also substantially limited as a consequence of unequal rules for determination of the amount of the corporate income tax base, which result from tax legislation applicable in the individual states. Consequently, statutory tax rates may not hold the role of an impartial indicator for the purposes of mutual comparison of this burden in different states, and therefore economists had to come with a new measure for effective taxation of corporation. That was the implicit corporate tax rate, which are tax rates where consideration is taken not only of the amount of the statutory tax rates from corporations' incomes, but also other aspects of taxation systems determining the total amount of effectively paid taxes.

\footnotetext{
${ }^{16}$ SCHULTZOVÁ, A. Daňové sústavy štátov Európskej únie. Bratislava: Ekonom, 2007. ISBN 978-80-2252333-2.
} 
In connection with the recovery of the economy, until the prevalence of the financial crisis in 2008, a growth in the proportion of the income tax of legal persons can be observed. It goes without saying that the world economic crisis shall have negative effects on further development of corporate tax revenues, in spite of multiple measures which should have contributed to alleviation of the slump of economies. Already today some political leaders in finding solutions to the current economic crisis and in an effort to stabilize the budget they intend to propose to raise the income tax of enterprises. These days, some of the political elite, that are seeking points of departure from the current economic crisis and attempting to achieve budgetary stabilisation, intend to increase income tax of companies. I am convinced that an adequate intervention in indirect taxes rather than any adjustments of direct taxes would be a far more reasonable solution of the respective situation.

\section{References}

[1] BALDWIN, R. E., KRUGMAN, P.: Agglomeration, Integration and Tax Harmonization, 2002. [Online], [cit. 10. 9. 2010]. Url: http://www.sciencedirect.com/science/article/B6V64-48M7XY51/2/f75e1f092b9552c7b18af65fee07844f.

[2] BLECHOVÁ, B. Charakteristika přístupů používaných v EU pro hodnocení efektivního daňového zatížení př́ijmů korporací. In. Theoretical and Practical Aspects of Public Finance. VŠE Prague 2008. ISBN 978-80-245-1378-2.

[3] Income Tax Act, No. 586/1992 Coll., as amended

[4] KPMG's Corporate and Indirect Tax Rate Survey 2007 Url: http://www.kpmg.cz/czech/images/but/Corporate_and_Indirect_Tax_Rate_Survey_2007.pdf

[5] KPMG's Corporate and Indirect Tax Rate Survey 2009 Url: http://www.kpmg.com/Global/en/IssuesAndInsights/ArticlesPublications/Documents/K PMG-Corporate-Indirect-Tax-Rate-Survey-2009.pdf

[6] KUBÁTOVÁ, K. Daňová teorie a politika. Edition 4. Prague: ASPI, 2006. ISBN 807357-205-2.

[7] REDOANO, M. Fiscal Interactions Among European Countries. Does the EU Matter? [Online], [cit. 10. 9. 2010]. Url: http://www2.warwick.ac.uk/fac/soc/csgr/research/abstr acts/222/

[8] SCHULTZOVÁ, A. Daňové sústavy štátov Európskej únie. Bratislava: Ekonom, 2007. ISBN 978-80-225-2333-2.

[9] Taxation trends in European Union (Main results). Luxembourg: Publications Office of the European Union, 2010. ISBN 978-92-79-15802-5

[10] The Consolidated version of the Treaty on European Union and Treaty on Operation of European Union. In: Official Bulletin of European Union. 2008/C115/01. ISSN 17255163.

[11] VANČUROVÁ, A. a kol. Daňový systém ČR 2008 aneb učebnice daňového práva. Prague VOX, ISBN 978-80-86324-72-2.

[12] www.mfcr.cz

\section{Klasifikace JEL: K22, K34}

\section{Ing. Ivana Koštuříková, Ph.D.}

Silesian University - School of Business Administration

Department of Accounting

Univerzitní nám. 1934/3

73340 Karviná

kosturikova@opf.slu.cz 